\title{
Release of soluble phosphorus through biodegradation of poultry litter by Bacillus
}

\author{
T. M. El-Katony ${ }^{1 *}$, M. I. Abou-Dobara ${ }^{1}$, N. M. Hassan ${ }^{1}$, A. M. Badawi ${ }^{1}$, E. A. Ghozy ${ }^{1}$ \\ ${ }^{1}$ Botany Department, Faculty of Science, Damietta University, New Damietta City, Egypt.
}

Received: 24 May 2015 / Accepted: 19 September 2015

*Corresponding author: tmsoliman2000@yahoo.co.uk

\begin{abstract}
The mineral content of two types of poultry litter; that is from meat producing chickens (broilers) and from egg laying chickens (layers) was investigated. The egg poultry litter was superior to meat poultry litter in the mineral composition, and its mineral content (\% DW) was $\mathrm{P} 3.5, \mathrm{~K} 3, \mathrm{Ca} 9, \mathrm{~N}$ 2.4, $\mathrm{Mg} \mathrm{0.5}$, and $\mathrm{Fe} 1.2$ in addition to moderate levels of $\mathrm{Mn}, \mathrm{Zn}, \mathrm{Cu}$ and Mo. The litter content of the toxic heavy metals was small; ranging from $2.6 \mathrm{ppm}(\mathrm{mg} \mathrm{kg}-1)$ for $\mathrm{Cd}$ and $7.4 \mathrm{ppm}$ for $\mathrm{Pb}$ to relatively high levels of As (36.3 ppm).

The microbial content of egg poultry litter was dense and amounted to $2 \times 106$ Colony Forming Unit (CFU) per g dry litter, distributed among twenty four bacterial isolates and seven isolates of actinomycetes; and the bacterial isolates were sorted into twenty-one Gram positive endosporeforming rods and three Gram negative rods. Each of the twenty four bacterial isolates were incubated with sterile egg poultry litter and the release of inorganic phosphorus (Pi) was monitored over time for a period of 20 days. Out of the 24 bacterial isolates three exhibited outstanding ability to release Pi from litter; and from these three isolates, one was selected for further cultural, microscopic and physiological investigations, and was identified as Bacillus subtilis. Upon incubation of Bacillus subtilis with litter the yield of Pi increased progressively with time from an initial value of $0.86 \mathrm{mg}$ Pi g-1 litter to $2.17 \mathrm{mg} \mathrm{Pi} \mathrm{g-1} \mathrm{litter} \mathrm{by} \mathrm{the} \mathrm{fifteenth} \mathrm{day,} \mathrm{beyond} \mathrm{which} \mathrm{it} \mathrm{leveled} \mathrm{off} \mathrm{up} \mathrm{to} \mathrm{the}$ twentieth day.
\end{abstract}

Keywords: Arsenic, Bacillus subtilis, biodegradation, phosphorus, poultry litter.

\section{Introduction}

Phosphorus is the second key plant nutrient after nitrogen; it is essential for many physiological activities such as cell division, photosynthesis, root proliferation, utilization of carbohydrates and energy metabolism in general. Soil P is primarily found in the organic form and the concentration of soluble $\mathrm{P}$ in soil is usually very low (Marschner, 1995). The overall $P$ use efficiency of plants is low because of the formation of insoluble salts with soil minerals, particularly aluminum, iron and calcium; which necessitates frequent application of soluble $P_{i}$ to the soil. Nevertheless, with excessive application of $P$ fertilizers, leaching of $P_{i}$ from the surface soil into ground water would 
result in eutrophication of aquatic systems (Del Campillo et al., 1999).

The use of animal manures as bio-fertilizers seems a tempting practice in recent agriculture. Among the commonly used organic wastes for soil fertilization is poultry litter. Poultry litter consists primarily of poultry manure, mixed with the original bedding material, feathers, and spilled feed. Monogastric animals such as poultry and swine are not as efficient at utilizing organic $\mathrm{P}$ (phytin) in the feed as are cattle. Furthermore, the diets of these animals are often supplemented by mineral $\mathrm{P}$ additions. Therefore, poultry litter is particularly rich in $\mathrm{P}$ which amounts to about 9.8 $27.1 \mathrm{~g} \mathrm{~kg}^{-1}$. In addition, the litter contains appreciable amounts of nitrogen in the form of undigested proteins and uric acid, carbohydrates in the form of cellulose, starch and soluble sugars, lipids and minerals including $\mathrm{Ca}, \mathrm{K}, \mathrm{Mg}, \mathrm{S}$ and micronutrients (Kelleher et al., 2002; Pote et al., 2003). Since most of the elements contained in poultry litter are in the organic form, they are not readily available to the plant after immediate application.

The advantage of litter over the traditional chemical fertilizers is that litter acts both as a fertilizer and also as a soil conditioner; for it furnishes the soil with organic matter. Organic matter improves soil structure and increases the holding capacity of the soil for water and nutrients. Consequently, organic fertilizers provide the plant with a moderate steady level of balanced nutrient supply which ensures consistent growth and development; this in contrast to the application of chemical fertilizers where there is mostly a sudden increase in the level of one nutrient, which disrupts the nutrient balance within the soil and lead to luxury consumption by the plant or even toxicity. Application of poultry litter increases $\mathrm{P}$ accumulation in surface soils, and the magnitude of increase depends on application rates and frequencies (Liechty et al., 2009). Currently, the main purpose of managing soil phosphorus is to optimize crop production, and meanwhile to minimize P loss from soils. Recently, phosphate solubilizing microorganisms have attracted considerable attention as soil inocula to improve plant growth and yield (Goldstein et al., 1999). Plant growth-promoting bacteria (PGPB) are soil and rhizosphere bacteria that can benefit plant growth by different mechanisms (Glick, 1995); among which is their P-solubilization ability. Soil microorganisms are effective in releasing $\mathrm{P}$ from inorganic and organic pools of soil $\mathrm{P}$ through solubilization and mineralization (Hilda and
Fraga, 1999). Solubilization of mineral phosphate by phosphorus solubilizing bacteria (PSB) is generally mediated by the release of low molecular weight organic acids (Goldstein et al., 1999; Gyaneshwar et al., 2002), while the release of $\mathrm{Pi}$ from organic $\mathrm{P}$ compounds is mediated by production of phosphatase enzymes; and species of Pseudomonas, Bacillus, Rhizobium and Enterobacter are the most efficient in this respect (Whitelaw, 2000). In addition, these bacteria also produce other bioactive materials such as vitamins and the growth promoting hormones: auxins and gibberellins (He et al., 2002). Application of both phosphorus solubilizing bacteria (PSB) and plant growth-promoting bacteria (PGPB) increased $\mathrm{P}$ uptake efficiency by $50 \%$ and also increased the contents of nitrogen, potassium, calcium and iron in the plant leaves and fruits (Yazdani et al., 2009). Poultry litter has usually a large number of inhabiting microorganisms. The average density of viable microorganisms in poultry pine-sawdust litter was $6.3 \times 10^{7} / \mathrm{g}$ dry material, $1-6 \%$ of which was aerobic heterotrophic bacteria and the density of acidophilic bacteria, aerobic spore-forming bacteria, actinomycetes and fungi were $4.8 \times 10^{4}, 8.1 \times 10^{4}, 5.2 \times 10^{4}$ and $8.9 \times 10^{4}$ colony forming unit (CFU) per gram respectively (Nodar et al., 1990).

The present work aims to evaluate the mineral content of two kinds of poultry litter from Damietta Province, and to investigate the potentiality of the inhabiting microflora to release $\mathrm{P}_{\mathrm{i}}$ from litter. This ultimately aims at screening and identification of the most efficient bacterial species for further use of poultry litter as a biofertilizer for crop plants.

\section{Materials and methods}

\section{Chemicals}

Chemicals used in this work were obtained from Sigma (Sigma Chemical Co. Poole, Dorest, England) unless otherwise stated

\section{Collection of Poultry litter samples}

Poultry litter samples used in this work were collected from poultry farms in the Damietta province, Egypt. Two types of litter were collected; that is from meat producing chickens (broilers) and egg laying chickens (layers). 
Determination of water holding capacity and $\mathrm{pH}$ of litter

Water holding capacity and $\mathrm{pH}$ of litter was determined according to Allen et al. (1986).

\section{Extraction of the total and soluble minerals of litter}

For determination of the total mineral content of litter, dried poultry litter was ground into a fine powder prior to digestion by the sulfuric acid/hydrogen peroxide method of Allen et al. (1986). Digestion mixture was prepared by mixing $0.42 \mathrm{~g}$ selenium and $14 \mathrm{~g}$ lithium sulfate hydrated in a one-liter flask. To the mixture, $350 \mathrm{ml} \mathrm{H}_{2} \mathrm{O}_{2}$ (100 volume) and $420 \mathrm{ml}$ conc. $\mathrm{H}_{2} \mathrm{SO}_{4}$ were added slowly, in order, with cooling. Five $\mathrm{ml}$ of the digestion mixture were added to $50-100 \mathrm{mg}$ of litter in a Kjeldhal digestion flask. The digestion flasks were heated gradually until the white fumes were cut off. After cooling the extract was made up to $50 \mathrm{ml}$ in a volumetric flask. For determination of the soluble mineral fraction of litter, a known weight $(10 \mathrm{~g})$ of the dry litter was added to $150 \mathrm{ml}$ water in a $250 \mathrm{ml}$ conical flasks and the mixture was shaken using a Lab-Line Model No.3521 orbital shaker for an hour. The mixture was filtered and the content of minerals was determined in the clear extract.

\section{Determination of mineral composition of litter}

Phosphorus content was determined in the clear extract spectrophotometrically according to the method of John (1970). Nitrogen content was determined by the direct Nesslerization method of APHA (1992). The contents of K, Na and Ca were determined by using a PFP-7 flame photometer and those of $\mathrm{Cd}, \mathrm{Cu}, \mathrm{Zn}, \mathrm{Hg}, \mathrm{Fe}, \mathrm{As}, \mathrm{Mo}, \mathrm{Mg}, \mathrm{Mn}$, $\mathrm{Pb}$ by a Pye-Unicam SP 90 atomic absorption spectrophotometer.

\section{Isolation and counting of bacteria and actinomycetes from native poultry litter}

The dilution plate technique described by Johnson et al. (1959) was used for isolation of bacteria and actinomycetes. Under aseptic conditions $10 \mathrm{~g}$ of poultry litter were transferred into a conical flask containing $90 \mathrm{ml}$ of sterile water and the mixture was shaken for 20 minutes using a Lab-Line Model No.3521 orbital shaker. Serial dilutions of $10^{-1}$ to $10^{-6}$ were made from the supernatant. One $\mathrm{ml}$ of each dilution was transferred aseptically into sterile petri dishes and $20 \mathrm{ml}$ portions of nutrient agar for bacteria and starch-nitrate agar for actinomycetes were added with gentle mixing. After solidification, the dishes were incubated at $30 \mathrm{C}$ for $24-48$ hours for bacteria and 7 days for actinomycetes. The plates were examined and the colonies were counted and characterized. The screened most active isolated of bacteria was identified using growth characteristics and various physiological and biochemical activities according to Logan and Vos (2009) and The Procaryotes (1991).

\section{Morphology of the isolated bacterial colonies}

Bacterial colonies resulting from growth on the nutrient agar medium at $30 \mathrm{C}$ for 2 days were examined for the following characteristics: shape, transparency, margin, consistency, color and pigmentation. Gram reaction and endospore formation were also examined in cell suspension.

\section{Physiological and biochemical tests}

In addition to the morphological characteristics, several biochemical and physiological tests were carried out to identify the selected, most active bacterial isolate in release of $\mathrm{Pi}$ from litter. These tests included: (a) the ability to degrade: starch, gelatin, milk, urea, egg yolk (lecithinase production), tyrosine, citrate, propionate, phenylalanine, hydrogen peroxide (catalase test); (b) the ability to produce: nitrite (nitrate reduction), $\mathrm{H}_{2} \mathrm{~S}$, indole, dihydroxyacetone, acid and gases from glucose, acetylmethylcarbinol from glucose (Voges-Proskauer test), acid from: D-glucose, L-arabinose, D-xylose and D-mannitol and (c) growth at different concentrations of $\mathrm{NaCl}$, different temperatures and at $\mathrm{pH}$ of 5.7.

\section{Incubation of litter with bacteria}

Sterilized litter portions of equal weight were brought to $80 \%$ of water holding capacity and inoculated with equal number of cells of the different isolates and incubated at $30^{\circ} \mathrm{C}$ and $\mathrm{P}_{\mathrm{i}}$ released from incubated poultry litter was determined in the clear water extract at frequent intervals using the procedure of John (1970).

\section{Results}

The total phosphorus content was 50\% higher in the egg poultry litter than in the meat poultry litter 
(Fig.1). Therefore, egg poultry litter was used for the detailed subsequent investigation. The egg poultry litter lot used in the present work was characterized with a moderate $\mathrm{pH}$ (7.97), fairly high water holding capacity (124\%) and appreciable contents of plant nutrients, particularly $\mathrm{P}$ (Table 1); and the content of nutrients (\% DW basis) was: P 3.5, K 3, Ca 9, N $2.4, \mathrm{Mg} 0.5, \mathrm{Fe} 1.2$, in addition to moderate content of the micronutrients $\mathrm{Mn}, \mathrm{Zn}, \mathrm{Cu}$ and $\mathrm{Mo}$. The litter content of toxic heavy metals was low; ranging from $2.6 \mathrm{ppm}\left(\mathrm{mg} \mathrm{kg}^{-1}\right)$ for $\mathrm{Cd}$ and 7.4 $\mathrm{ppm}$ for $\mathrm{Pb}$ to $36.3 \mathrm{ppm}$ for As. The soluble fraction of the mineral content of litter was in general low and ranged from (\% of total content) 29 for $\mathrm{Mg}$ to $11-17$ for $\mathrm{Cd}, \mathrm{Na}$ and $\mathrm{Cu}$ and to extremely low values $(0.15 \%$ for $\mathrm{As}$ and $\mathrm{Ca}$ and $0.01 \%$ for $\mathrm{Fe}$ ).

Investigation of the microflora inhabiting fresh egg poultry litter returned a dense population of microorganisms $\left(2 \times 10^{6} \mathrm{CFU} \mathrm{g}{ }^{-1} \mathrm{DW}\right)$, which was distributed among 24 bacterial isolates and seven isolates of actinomycetes. The 24 bacterial isolates were examined microscopically with regard to Gram reaction and spore formation. These isolates were sorted into the following three categories: 14 isolates of Gram positive spore former solitary rods with central oval spores, seven isolates of Gram positive spore former chains of rods with central oval spores and three Gram negative rods (Fig. 2).

In addition, each of the 24 bacterial isolates was incubated with sterile egg poultry litter and the release of $\mathrm{P}_{\mathrm{i}}$ was monitored at time intervals for a period of 20 days. The time course of $P_{i}$ release exhibited different patterns in the different isolates (Fig.3). Three isolates (8, 9 and 24) exhibited outstanding activity to release $\mathrm{P}_{\mathrm{i}}$ from the litter compared to the other isolates. These isolates were subjected to further investigation and isolate number 8 was chosen for identification since it showed a progressive increase in $\mathrm{P}$ release with time up to 15 days. The activity of the screened bacterial isolate in release of $\mathrm{Pi}$ from litter was markedly diminished with sequential culturing. The initial maximum activity of isolate 8 was as high as $6.8 \mathrm{mg} \mathrm{P}_{\mathrm{i}} \mathrm{g}^{-1}$ litter (Fig.3); this was reduced to $2.23 \mathrm{mg} \mathrm{P}_{\mathrm{i}} \mathrm{g}^{-1}$ litter in the second and third cultures (Figs. 4 and 5). In addition, the time course of release of $P_{i}$ from litter varied with subsequent culturing. In the first culture, $P_{i}$ release by isolates 8, 9 and 24 exhibited a common pattern; a transient reduction on the tenth day, followed by a sharp rise by the fifteenth day and finally a reduction by the twentieth day of incubation (Fig.
3). In the second culture the time course of $\mathrm{P}_{\mathrm{i}}$ release differed among isolates but was of lesser magnitude compared to the first culture (Fig.4). In the third culture of isolate $8, \mathrm{P}_{\mathrm{i}}$ release increased progressively with elapse of time reaching a maximum of $2.2 \mathrm{mg} \mathrm{g}^{-1}$ litter by day 15 (Fig. 5). The most efficient bacterial isolate in release of $\mathrm{P}_{\mathrm{i}}$ (isolate 8) exhibited the following characteristics: the colony was opaque, of irregular shape, soft consistency, yellowish white color, no pigmentation and entire margin. Microscopic examination revealed Gram positive spore forming rods, with central spore (Table 2). The physiological characteristics were categorized into degradative activities, assimilation of certain resources, production of specific compounds and growth in specific environments. The selected isolate exhibited ability to degrade casein, egg yolk, starch, citrate, $\mathrm{H}_{2} \mathrm{O}_{2}$ and urea but failed to degrade gelatin, tyrosine, propionate and phenylalanine. It had the ability to produce dihydroxyacetone, acetylmethylcarbinol and nitrite (nitrate reduction), but failed to produce $\mathrm{H}_{2} \mathrm{~S}$, indole and acid from D-glucose, L-arabinose, $\mathrm{D}$-xylose and D-mannitol. The organism was a strict aerobe, salt sensitive and grew optimally at $30^{\circ} \mathrm{C}$ and $\mathrm{pH}$ 5.7. These characteristics evaluates this isolate to be Bacillus subtilis according to Bergey`s Manual of Systematic Bacteriology.

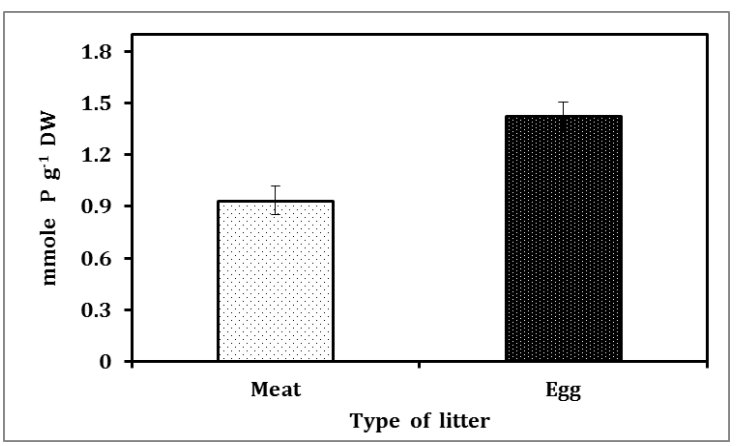

Fig. 1. Phosphorus content of egg and meat poultry litters. Each value is the mean of three replicates \pm SE.

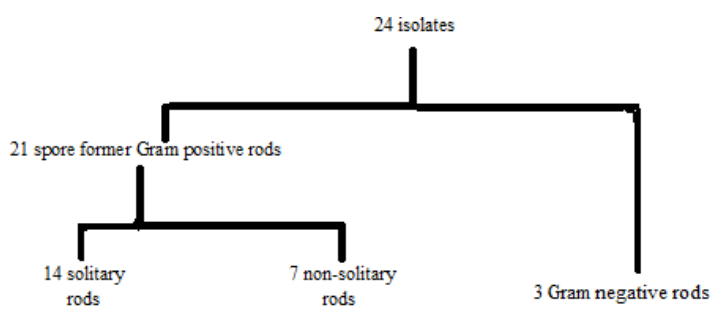

Fig. 2. Classification of the 24 bacterial isolates obtained from the poultry litter sample according to shape of cells, Gram reaction and endospore formation. 
Table 1. Composition of the poultry litter lot used in the present work. Each value is the mean of three replicates \pm SE. CFU is the number of colony forming units (viable cells), WHC is the water holding capacity. $\mathrm{ND}=$ not determined

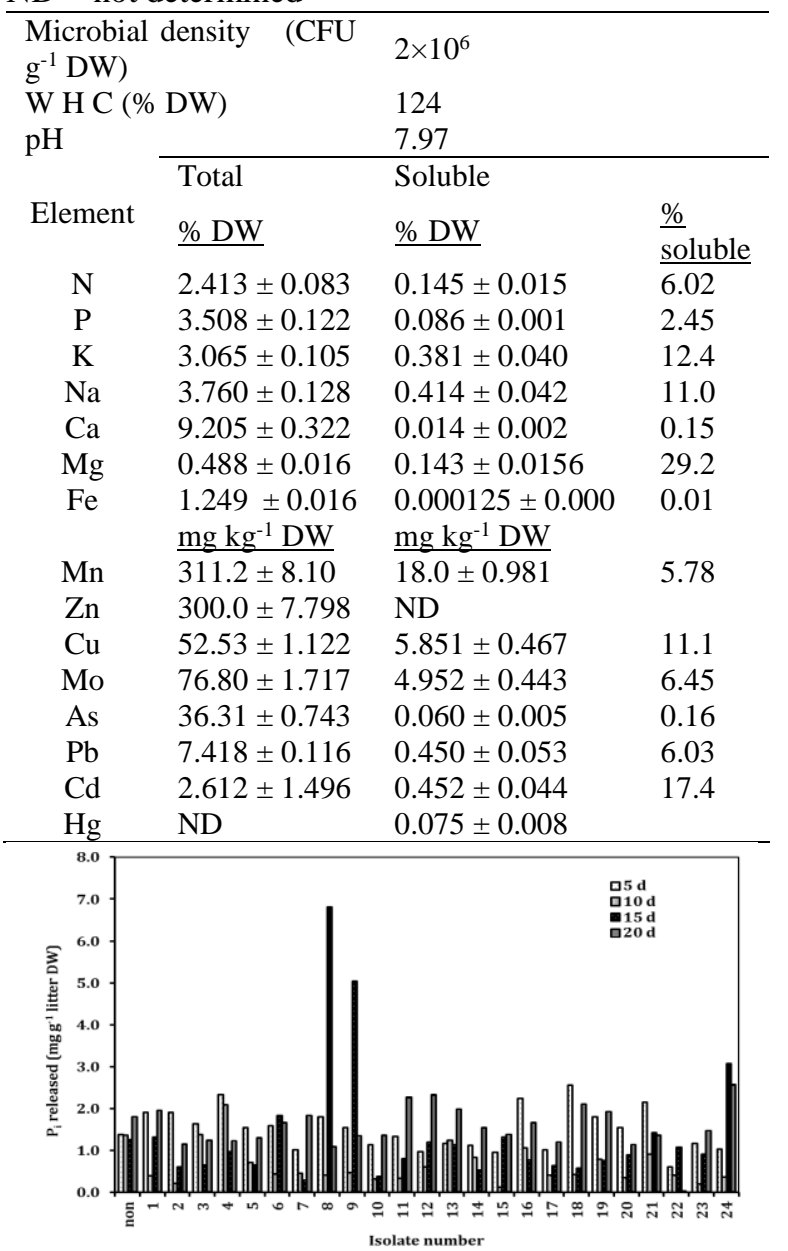

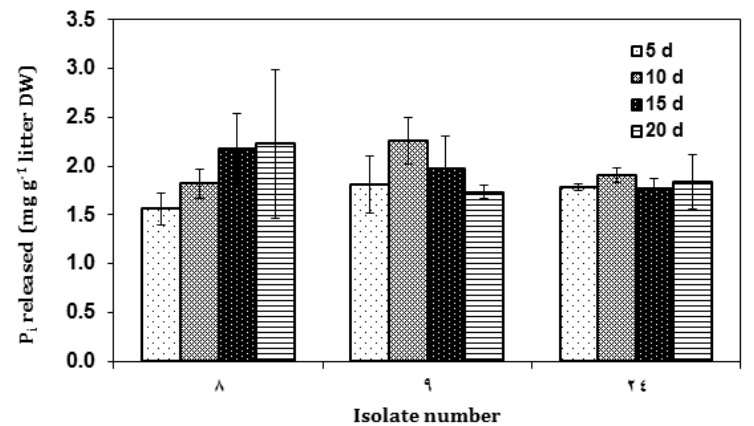

Fig. 4. Time course of release of inorganic phosphorus from poultry litter by the action of three selected bacterial isolates (isolates 8, 9 and 24). Each value is the mean of 2 replicates \pm SE.

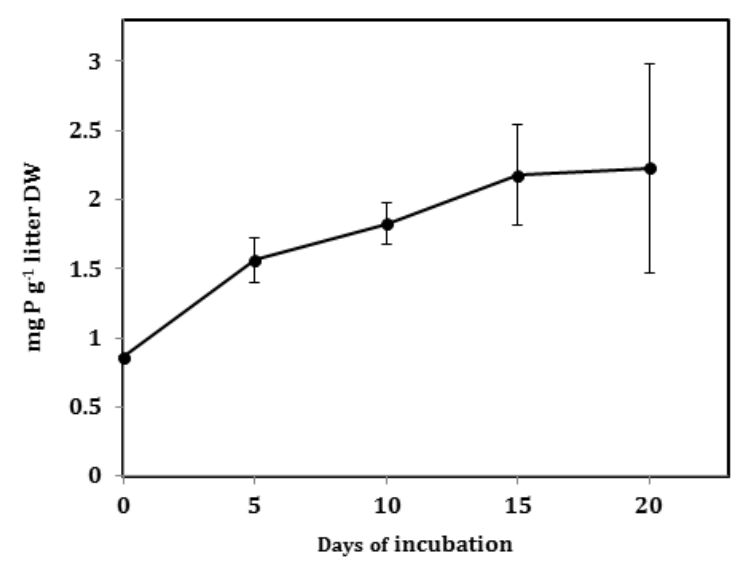

Fig. 5. Time course of release of inorganic $P$ from poultry litter incubated with the selected isolate of bacteria (isolate 8). Each value is the mean of 3 replicates $\pm \mathrm{SE}$.

Fig. 3. Time course of release of inorganic phosphorus $\left(\mathrm{P}_{\mathrm{i}}\right)$ from poultry litter by the action of 24 bacterial isolates.

Table 2. Colonial, microscopic and physiological and biochemical characteristics of the selected most active bacterial isolate in release of $\mathrm{P}_{\mathrm{i}}$ from litter (isolate 8).

\begin{tabular}{|c|c|c|c|}
\hline Character & Grade & Character & Grade \\
\hline Macroscopic (colonial) & & Production of: & \\
\hline Shape & Irregular & $\overline{\text { Nitrite (nitrate }}$ reduction) & + \\
\hline Consistency & Soft & $\mathrm{H}_{2} \mathrm{~S}$ & - \\
\hline Color & Yellowish white & Indole & - \\
\hline Transparency & Opaque & Dihydroxyacetone & + \\
\hline Pigmentation & Non & Gas from glucose & - \\
\hline Margin & Circle & $\begin{array}{l}\text { Acetylmethylcarbinol from glucose (Voges } \\
\text { Proskauer test) }\end{array}$ & + \\
\hline Microscopic & & Acid from carbohydrate: & \\
\hline Gram reaction & Gram +ve & D- glucose & - \\
\hline Spore forming & Spore former & L- arabinose & - \\
\hline Physiological and biochemical & & D- xylose & - \\
\hline Degradation (utilization) of: & & D- mannitol & - \\
\hline Casein & + & Growth at: & \\
\hline Starch & + & $0 \% \mathrm{NaCl}$ & +++++ \\
\hline Gelatin & - & $2 \% \mathrm{NaCl}$ & ++++ \\
\hline Urea & + & $5 \% \mathrm{NaCl}$ & +++ \\
\hline Proteolysis of egg yolk & + & $7 \% \mathrm{NaCl}$ & ++ \\
\hline
\end{tabular}




\begin{tabular}{l} 
Tyrosine \\
Citrate \\
Propionate \\
Phenyalanine \\
$\mathrm{H}_{2} \mathrm{O}_{2}$ (Catalase test) \\
\hline
\end{tabular}

\section{Discussion}

The amount of litter produced by the poultry farms is huge and represent an environmental problem; every broiler produces $1.46-2.67 \mathrm{~kg}$ of waste over its life span (Nachman et al., 2005). Nevertheless, these problematic wastes can be exploited, after composting by microorganisms, for several uses, among which is the addition to the soil as a bifertilizer. The high water holding capacity $(124 \%)$ of the litter, its moderate $\mathrm{pH}$ (7.97) and its high content of plant nutrients particularly $\mathrm{P}$ (up to $3.5 \%$ ) along with the fairly low content of toxic heavy metals evaluate the litter for use as a safe, economic and efficient biofertilizer and also as a soil conditioner, particularly for the dry low-in-organic matter sandy soils. Organic wastes are characterized with high water holding capacity, a feature of critical value for improving physicochemical properties of the soil in favor for plant growth. Thurow et al. (1987) reported water holding capacity of up to $300 \%$ for litter from different plant origins, where the magnitude differed according to plant species and litter texture. The $\mathrm{P}$ content of the egg poultry litter lot used in the present work (3.5\%) is higher than that reported by Kelleher et al. (2002) and Pote et al. (2003) which ranged from 0.98 to $2.71 \%$. This high $\mathrm{P}$ content justifies the use of litter as an efficient biofertilizer, particularly on the basis of plant $\mathrm{P}$ demand. An additional benefit of biofertilizers is their ability to enrich the soil with micro- and macro-nutrients via nitrogen fixation, phosphate and potassium solubilization or mineralization, release of plant growth regulating substances, production of antibiotics and biodegradation of organic matter in the soil (Sinha et al., 2014).

Poultry litter normally contains arsenic; which arises primarily from implementation of organoarsenic compounds in the treatment of poultry, which is a common practice in poultry farms worldwide. Organoarsenic compounds such as roxarsone are used as a feed additive for control of fungal diseases and for weight gain improvement in poultry farms in the United States (Jones, 2007).There are no regulatory standards for trace elements concentrations in poultry litter; only municipal biosolids have regulatory limits
$10 \% \mathrm{NaCl}$

pH 5.7

$5^{\circ} \mathrm{C}$

$30^{\circ} \mathrm{C}$

$50^{\circ} \mathrm{C}$

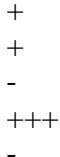

for trace metals and these are 20, 750, and 1400 $\mathrm{mg} \mathrm{kg}{ }^{-1}$ for $\mathrm{As}, \mathrm{Cu}$, and $\mathrm{Zn}$ respectively in soil amended with biosolids (Miller and Miller, 2000). These standards are often used as a reference for the other land-applied wastes (Ashjaei et al., 2011). Thus, the level of As encountered in the used litter lot $\left(36.3 \mathrm{mg} \mathrm{kg}^{-1}\right)$ can be considered moderate and do not seem to impose a serious environmental risk, for it slightly exceeded the allowable limits. Furthermore, the situation seems less severe in the light of the fact that a negligible fraction of the arsenic content of litter $(0.16 \%)$ is in the soluble from. In this respect, Han et al. (2004) reported that about $47 \%$ of As in poultry litter occur in the hazardous, water-soluble pool. Likewise, the litter content of $\mathrm{Cu}$ and $\mathrm{Zn} \mathrm{(52} \mathrm{and}$ $300 \mathrm{mg} \mathrm{kg}^{-1}$ respectively) are by far below the above mentioned regulatory limits and the soluble fraction of $\mathrm{Cu}$ amounted to only $16 \%$ of the total $\mathrm{Cu}$ in the litter.

In addition to its high content of plant nutrients, egg poultry litter is also rich in microorganisms which occur in a great variety and high density. Incubation of the native litter at appropriate conditions yielded a dense population of inhabiting microorganisms $\left(2 \times 10^{6} \mathrm{CFU} \mathrm{g}{ }^{-1} \mathrm{DW}\right)$ which was distinguished into 24 different bacterial isolates, mostly spore former Gram positive rods, and seven isolates of actinomycetes. This seems reasonable, hence poultry litter, by virtue of its high organic matter content and consequently its high water holding capacity, in addition to the moderate $\mathrm{pH}$ can host a dense and diverse population of microorganisms, particularly bacteria. The average density of viable microorganisms in poultry pine-sawdust litter

was $6.3 \times 10^{7} / \mathrm{g}$ dry matter; with small proportion of aerobic heterotrophic bacteria and the majority being acidophilic bacteria, aerobic spore-forming bacteria, actinomycetes and fungi which approached $4.8 \times 10^{4}, 8.1 \times 10^{4}, 5.2 \times 10^{4}$ and $8.9 \times 10^{4} \mathrm{CFU} / \mathrm{g}$ dry litter respectively (Nodar et al., 1990). This population of microorganisms is crucial for soil fertility and the integrity and efficient performance of the root system. Living roots can support even a more dense population of microorganisms which might approach up to $10^{11}$ microbial cells per gram of root in the rhizosphere (Egamberdieva et al., 2008). The rhizosphere microflora in general, 
includes a vast array of naturally occurring microorganisms which benefit the soil ecosystem through improving the soil physicochemical properties, plant growth and development and crop productivity (Singh et al., 2011; Sahoo et al., 2014).

The present results suggest that sequential culturing of the isolated bacteria affect both efficiency and time course of release of $P_{i}$ from litter. The activity of bacteria in $\mathrm{P}_{\mathrm{i}}$ release generally diminished with subsequent culturing. In addition, whereas in the earlier culture, $\mathrm{P}_{\mathrm{i}}$ release increased with the progress of incubation time reaching a maximum at specific time, post which it declined; in the latter culture the increase in $\mathrm{P}_{\mathrm{i}}$ releasing activity was progressive, reaching a limit at the end of incubation period but without subsequent decline. This might point to fluctuation in the relative efficiency of release and of consumption of $\mathrm{P}_{\mathrm{i}}$ by bacteria in the successive cultures. It seems that during the early periods of incubation with litter the activity of $P_{i}$ release exceeds that of its fixation by bacteria; but this balance was shifted in favor of the latter activity with the progress of time. The cultural, microscopic, biochemical, and physiological investigations of the selected most efficient bacterial isolate justifies its identification as Bacillus subtilis according to Logan and Vos (2009) and The Procaryotes (1991). In this respect, Pindi and Satyanarayana (2012) reported that among the active organisms in release of $\mathrm{P}_{i}$ are Pseudomonas, Bacillus and Micrococcus and that a key advantage of these bacteria is to assimilate phosphorus for their own use; which in turn becomes available for plant uptake. Furthermore, a phosphate-solubilizing bacterial strain NII-0909 of Micrococcus sp. has multiple roles including phosphate solubilization and siderophore production (Dastager et al., 2010).

\section{References}

Allen S. E., Grimshaw H. M., Rowland A. P. (1986). Chemical analysis. In: Moore PD, Chapman SB, editors. Methods in Plant Ecology. Oxford: Blackwell Scientific Publications; pp. 285-343.

APHA : American Public Health Association (1992). Standard Methods for Examination of Wastewater, 17th ed. American Public Health Association, Washington; D.C; p.116.

Ashjaei S., Miller W. P., Cabrera M. L., Hassan S. M. (2011). Arsenic in soils and forages from poultry litter-amended pastures. Int. J. Environ. Res. Public Health 8: 1534-1546.
Dastager S. G., Deepa C. K., Pandey A. (2010). Isolation and characterization of novel plant growth promoting Micrococcus sp NII-0909 and its interaction with cowpea. Plant Physiol. Biochem. 48:987-992.

Del Campillo S. E., Van der Zee S. E. A. T. M., Torrent J. (1999). Modelling long-term phosphorous leaching and changes in phosphorous fertility in excessively fertilized acid sandy soils. Eur. J. Soil Sci. 50, 391-399..

Egamberdieva D., Kamilova F., Validov S., Gafurova L., Kucharova Z., Lugtenberg B. (2008). High incidence of plant growth stimulating bacteria associated with the rhizosphere of wheat grown on salinated soil in Uzbekistan. Environ. Microbiol. 10:1-9.

Glick B. R. (1995). The enhancement of plant growth by free-living bacteria. Can. J. Microbiol. 41: 109117.

Goldstein A. H., Braverman K., Osorio N. (1999). Evidence for mutualism between a plant growing in a phosphate-limited desert environment and a mineral phosphate solubilizing (MPS) rhizobacterium. FEMS Microbiol. Ecol. 30: 295300 .

Gyaneshwar P., Kumar G. N., Parekh L. J., and Poole P. S. (2002). Role of soil microorganisms in improving $\mathrm{P}$ nutrition of plants. Plant and Soil, 245: 83-93.

Han F. X., Kingery W. L., Selim H. M., Gerard P. D., Cox M. S., Oldham J. L. (2004). Arsenic solubility and distribution in poultry waste and long-term amended soil. Sci. Total Environ. 320: 51-61.

He Z .L., Bian W., Zhu J. (2002). Screening and identification of microorganisms capable of utilizing phosphate adsorbed by goethite Commun. Soil Sci. Plant Anal. 33: 647-663.

Hilda R., Fraga R. (1999). Phosphate solubilizing bacteria and their role in plant growth promotion. Biotechnol. Adv. 17: 319-339.

John M. K. (1970). Colorimetric determination of phosphorus in soil and plant materials with ascorbic acid. Soil Sci. 109: 214-220.

Johnson L. F., Curl E. A., Bond J. H., Fribourg H. A. (1959). Methods for Studying Soil Microflora Plant disease relationships, Burgess Pub. Co., Minneapolis.

Jones F. T. (2007). A broad view of arsenic. Poult. Sci. 86: $2-14$

Kelleher B. P., Leahy J. J., Henihan A. M., O’Dwyer T. F., Sutton D., Leahy M.J. (2002). Advances in poultry litter disposal technology - a review. Bioresource Technology 83:27-36.

Liechty H. O., Blazier M. A., Wight J. P., Gaston L. A., Richardson J. D. and Ficklin R. L. (2009). Assessment of repeated application of poultry litter on phosphorus and nitrogen dynamics in loblolly 
pine: Implications for water quality. Forest Ecology and Management 258: 2294-2303

Logan N. A., Vos P. DE. (2009). Genus I. Bacillus. In: Bergey's Manual of Systematic Bacteriology. Volume Three The Firmicutes. Pp. 21. Springer.

Marschner H. (1995). Mineral Nutrition of Higher Plants (2nd edition). Academic press, London. 889 P.

Miller D. M., Miller W. P. (2000). Handbook of Soil Science. Sumner, M.E., Ed.; CRC Press: Boca Raton, FL, USA, pp. G217-241.

Nachman K. E., Graham J. P., Price L. B., Silbergeld E.K. (2005). Arsenic: A roadblock to potential animal waste management solutions. Environ. Health Perspect. 113: 1123-1124.

Nodar R., Acea M. J., Carballas T. (1990). Microbial populations of poultry pine-sawdust litter. Biological Wastes 33: 295- 306

Pindi P. K., Satyanarayana S. D. V. (2012). Liquid microbial consortium- a potential tool for sustainable soil health. Journal of Biofertilizers and Biopesticides. 3:1-9.

Pote D. H., Kingery W. L., Aiken G.E., Han F. X., Moore Jr. P.A., Buddington, K. (2003). Waterquality effects of incorporating poultry litter in perennial grassland soils. J. Environ. Qual. 32: 2392-2398.

Sahoo R. K., Ansari M. W., Dangar T. K., Mohanty S., Tuteja N. (2014). Phenotypic and molecular characterization of efficient nitrogen fixing
Azotobacter strains of the rice fields for crop improvement. Protoplasma 251:511-523.

Singh J. S., Pandey V. C., Singh D. P. (2011). Efficient soil microorganisms: a new dimension for sustainable agriculture and environmental development. Agric. Ecosyst. Environ. 140:339353.

Sinha R. K., Valani D., Chauhan K., Agarwal S. (2014). Embarking on a second green revolution for sustainable agriculture by vermiculture biotechnology using earthworms: reviving the dreams of Sir Charles Darwin. Int. J. Agric. Health Saf. 1:50-64.

The Prokaryotes (1991). A Handbook on Habitats, Isolation and Identification of Bacteria. (Eds. Starr, Stolp, Trüper, Balows and Schlegel). SpringerVerlag, Berlin.

Thurow T. L., Blackbum W.H., Warren S. D., Tavlor Jr C. A. (1987). Rainfall interception by midgrass, shortgrass, and live oak mottes. J. Range Manage. 40:455-460.

Whitelaw M.A. (2000). Growth promotion of plants inoculated with phosphate solubilizing fungi. Adv. Agron. 69:99-151.

Yazdani M., Bahmanyar M. A., Pirdashti H., Esmaili M. A. (2009). Effect of phosphate solubilization microorganisms (PSM) and plant growth promoting rhizobacteria (PGPR) on yield and yield components of corn (Zea mays L.). World Acad. Sci. Eng. Tech. 49: 90-92.

\section{الملخص العربي}

عنوان البحث: تحرير الفوسفور الأيائ من خلال التحلل الحيوى لمخلفات الدواجن باستخدام بكتيريا Bacillus subtilis

طله محمد القاطونى '، محمد اسماعيل أبو دبارة'، نعمث محمد حسن' ، عبد الحكيم محمد بدوى '، ايناس عبد اللطيف ا قسم النبات ـ كلية العلوم - جامعة دمياط

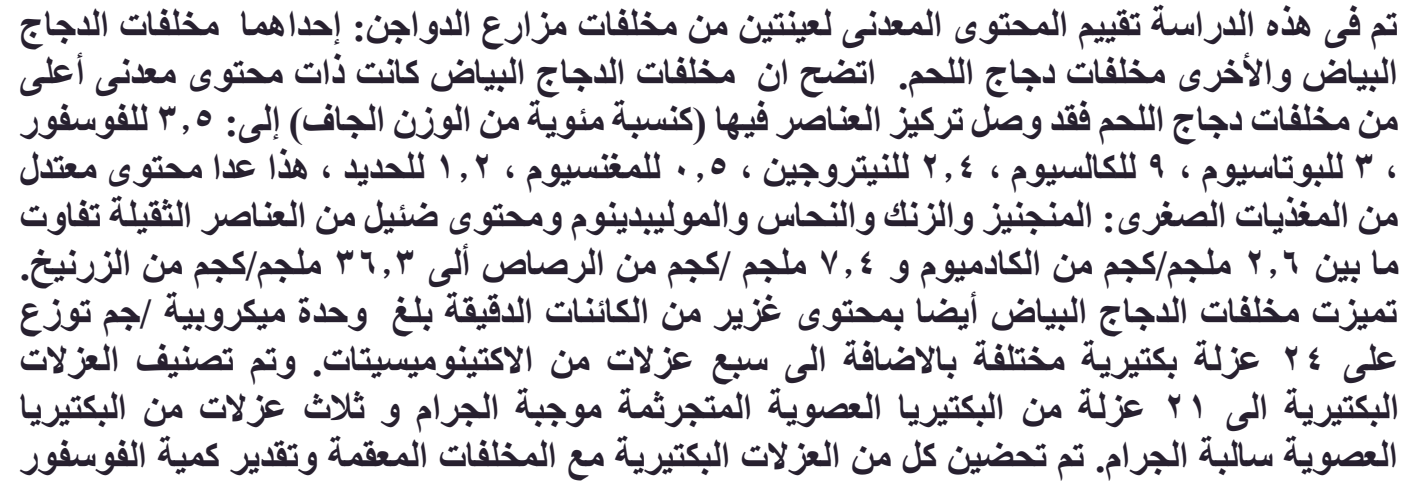




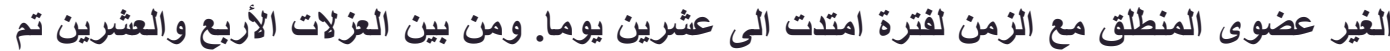

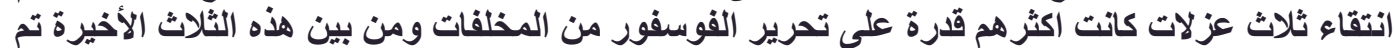

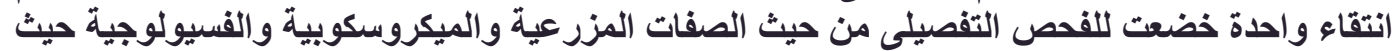

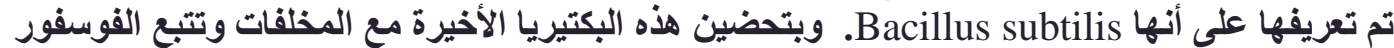

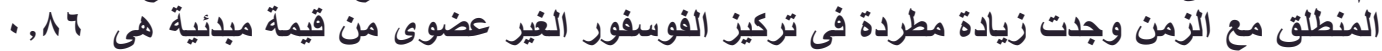

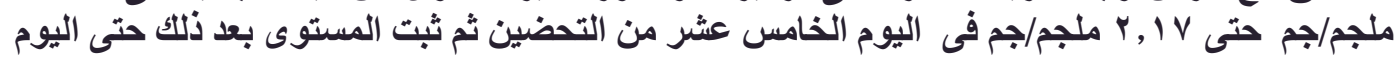

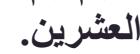

